\title{
Attempts to Create Wheat (Triticum aestivum L.) Superior High- Yielded Variety through Mutation Breeding
}

\author{
Irfan Suliansyah ${ }^{\#}$, Irawati Chaniago ${ }^{\#}$, Hendra Alfi ${ }^{*}$ \\ \# Department of Agroecotechnology, Faculty of Agriculture Andalas University Padang 25163, Indonesia \\ E-mail: irfan.suliansyah@yahoo.com
}

*Payakumbuh Agricultural Polytechnic, Jl. Raya Negara km. 7 Sarilamak 26271, Indonesia

\begin{abstract}
Experiments to determine radiation dose effective for increasing wheat genetic diversity has been conducted from March to May 2015. Wheat seeds radiation was carried out at Research Center and PATIR BATAN, South Jakarta, followed by wheat growth screening at greenhouse of PATPKP UNAND at Alahan Panjang, Municipality of Solok, the Province of West Sumatra. Wheat genotypes of IS-Jarissa dan GURI 6 UNAND were subjected to gamma radiation as follow: $0.1 ; 0.2 ; 0.3 ; 0.4 ; 0.5 ; 0.6 ; 0.7 ; 0.8$; $0.9 ; 1.0 \mathrm{kGy}$; and $0 \mathrm{kGy}$ as control treatment. The wheat seeds were then grown in a mixture of soil and cow manure (3:1) w/w in a greenhouse. Data demonstrated that increasing the radiation doses resulted in decreasing in wheat growth. The effective doses of gamma radiation were 0.2 and $0.3 \mathrm{kGy}$. No wheat grown observed from the treatment groups of $0.5 \mathrm{kGy}$ gamma radiation and higher.
\end{abstract}

Keywords - wheat, mutation, irradiation.

\section{INTRODUCTION}

Wheat (Triticum aestivum L.) is not originated from Indonesia; however, wheat flour has become major source of carbohydrate, is only second to rice. Wheat consumption of Indonesian people increases annually and has reached 21.2 $\mathrm{kg} /$ person/year in 2011. This figure makes a $500 \%$ increase within 30 the last [1]. To meet the demands for wheat flour, Indonesia has to import from various countries. Reference [2] reported that in 2014 Indonesia imported wheat as much as 7.5 millions tons, and has placed Indonesia as the second largest wheat importing country in the world.

Indonesia has tried various efforts to suppress the everincreasing wheat import. Adapting wheat to the tropical Indonesian conditions and climates is of important attempt. Research on adaptation and multi-locations testing of Slovak origin wheat genotypes resulted in fairly good wheat adaptation in Indonesia [3], [4], [5], [6]. However, some high-yielded genotypes have long life span. Therefore, there is a need to breed new wheat variety with desired traits such as short life span, high yield, and more adaptive to tropical conditions.

Plant breeding may create or broaden plant genetic variability which in turn helps the breeder to select and determine desired traits. There are methods to increase plant genetic variability such as mutation technique as commonly known as mutation breeding [7], [8], [9], [10], [11].
Mutation breeding may help in reaching the goal of breeding program faster than that of conventional breeding. Mutation breeding has become an appropriate option to improve plant characters when conventional breeding does not work, or the desired traits were recessive, or improving another character in an established plant variety, or improving one or two main character(s) [12], [13]. Mutation breeding can be applied to improve a specific character without changing other characters. Furthermore, it may create a new character that was not belong to parental plants.

Mutagen may be applied to speed up the process of mutation. Physical mutagen such as gamma irradiation may be used in changing genetic constitute of plant genom towards desired character with high genetic variability [14], [15]. Research on induced mutation on banana plants resulted in five mutant genotypes resistant to Fusarium wilt [16]. Reference [17] reported that induced mutation shortened harvesting time of some West Sumatran landrace rice.

Research reported here aimed at improving wheat characters focusing on wheat life span and yield through mutation breeding. It was expected that the wheat mutant had short life span and high yielded. At the preliminary stage, the objective of this research was to determine the most effective irradiation doses to increase wheat genetic variability. 


\section{MATERIALS AND METHODS}

The research has been conducted from March to May 2015. Wheat seeds radiation was carried out at Research Center and PATIR BATAN, South Jakarta, followed by wheat growth screening at greenhouse of PATPKP UNAND at Alahan Panjang, Municipality of Solok, the Province of West Sumatra.

Wheat genotypes of IS-Jarissa dan GURI 6 UNAND were subjected to gamma radiation as follow: $0.1 ; 0.2 ; 0.3 ; 0.4$; $0.5 ; 0.6 ; 0.7 ; 0.8 ; 0.9 ; 1.0 \mathrm{kGy}$; and $0 \mathrm{kGy}$ as control treatment. The wheat seeds of $150 \mathrm{~g}$ and $14 \%$ moisture content for each genotype were put into paper bag prior to gamma-ray-irradiated with irradiator ${ }^{60} \mathrm{Co}$ Gammacell 220.

The wheat seeds were then grown in a mixture of soil and cow manure $(3: 1)$ w/w in a greenhouse. Two hundreds seeds of each treatment group were germinated in seed beds and were grown for three weeks. Data collected including seedling height, $\%$ of dead seeds, $\%$ of viable seeds, root length.

\section{RESULTS AND DISCUSSION}

The wheat seeds used for this research were parts of the collection at PATPKP UNAND at Jorong Galagah, Kenagarian Alahan Panjang, Kecamatan Lembah Gumanti, Kabupaten Solok. Those seeds were harvested at September 2014. Wheat genotype IS-Jarissa was introduced in 2011 from Istropol Solary as, Slovak Republic.

Reference [3] reported that genotype IS-Jarissa posses some good traits such as high number of tillers which directly increase the number and the length of panicles. As a consequence, the number of grains increased accordingly. However, this genotype flowers and matures late. Another genotype tested, SO3 which also was introduced form Slovak Republic has been registered and released in late 2014 as wheat var. GURI 6 UNAND. This variety has some advantages such as adaptive to the medium-high elevation of > $600 \mathrm{~m}$ above sea level, resistant to leaf blast (Helminthosporium sativum), and yield potential for 5.3 tones/ha. Despite its superior traits, var. GURI 6 UNAND indicated low productivity specially when grown at medium elevation.

The weed seeds used for this research were irradiated at PATIR BATAN, Pasar Jumat, South Jakarta. Seeds of each genotypes, $150 \mathrm{~g}$, was put into plastic bag prior to irradiated with gamma rays at the following doses: $100 ; 200 ; 300 ; 400$; $500 ; 600 ; 700 ; 800 ; 900$; and 1000 Gray using irradiator ${ }^{60} \mathrm{Co}$ Gammacell 220 (Figure 1). The seeds' moisture content was $\pm 14 \%$ and the iradiated seeds were presented at Figure 2 .

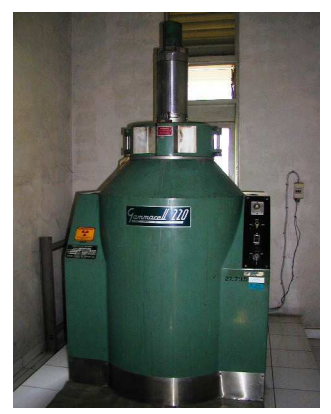

Fig. 1. Irradiator ${ }^{60} \mathrm{Co}$ Gammacell 220 at PATIR BATAN

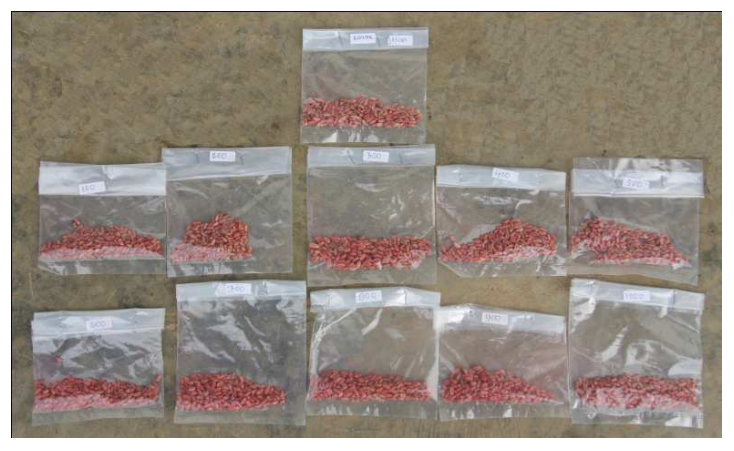

Fig. 2. Irradiated wheat seeds genotype IS-Jarissa, ready to be planted

The screening stage aimed to determine the effect of irradiation on the germination and growth of wheat plants. At this stage, all previously irradiated seeds including the controltreatment group were germinated and observed in seed bed for 3 weeks (Figure 3). The screening stage was carried out at the green house of PATPKP UNAND. It was expected that the effective dose of gamma ray would result in high variability of wheat mutants. This information is pertinent in the process of selection the mutants with early maturity trait in each genotype tested. Variable observed at this stage were seedling growth and the percentage of living plants (Table 1).

TABLE I

PERCENTAGE OF LIVING SEEDLINGS, PLANT HEIGHT, AND ROOT LENGTH OF WHEAT (3 WAP) IN RESPONSE TO VARIOUS LEVELS OF GAMMA RAY IRRADIATION.

\begin{tabular}{|l|r|r|r|r|r|r|r|}
\hline \multirow{2}{*}{ Genotipe } & \multicolumn{7}{|c|}{ Dosis (Gy) } \\
\cline { 2 - 9 } & $\mathbf{0}$ & $\mathbf{1 0 0}$ & $\mathbf{2 0 0}$ & $\mathbf{3 0 0}$ & $\mathbf{4 0 0}$ & $\mathbf{5 0 0}$ & $\begin{array}{r}\mathbf{6 0 0} \text { - } \\
\mathbf{1 0 0 0}\end{array}$ \\
\hline \multicolumn{7}{|c|}{ Living Seeds (\%) } \\
\hline GURI6 UNAND & 100,0 & 98,1 & 70,4 & 35,8 & 29,6 & 0,0 & 0,0 \\
\hline IS-Jarissa & 100,0 & 78,7 & 45,8 & 13,6 & 2,1 & 1,7 & 0,0 \\
\hline \multicolumn{7}{|c|}{ High Seeds (cm) } \\
\hline GURI6 UNAND & 36,0 & 36,6 & 29,7 & 22,2 & 11,7 & 0,0 & 0,0 \\
\hline IS-Jarissa & 32,0 & 26,1 & 24,3 & 13,6 & 4,9 & 3,6 & 0,0 \\
\hline \multicolumn{7}{|c|}{ Root Length (cm) } \\
\hline GURI6 UNAND & 7,9 & 7,0 & 4,9 & 4,3 & 2,6 & 0,0 & 0,0 \\
\hline IS-Jarissa & 6,9 & 6,4 & 7,3 & 5,8 & 4,1 & 3,1 & 0,0 \\
\hline
\end{tabular}

Table 1 clearly demonstrates that both GURI 6 UNAND and IS-Jarissa ceased to germínate when irradiated with gamma ray at 500 and 600 gray, respectively. Higher dose resulted in zero germination in both genotypes. Figure 4 supports the germination data of the wheat growth following gamma ray irradiation. The higher the dose the severe the wheat growth. 


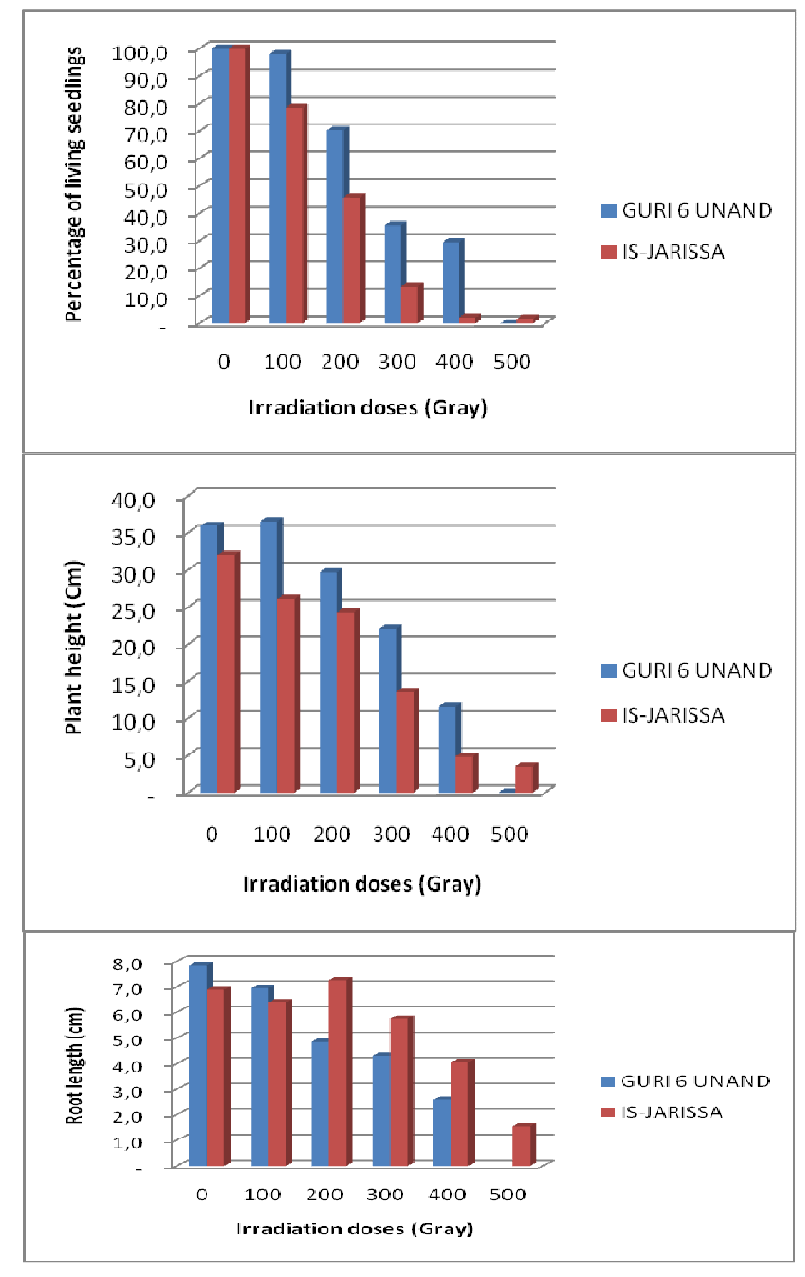

Fig. 3. Percentage of germination (above), plant height (middle), and root length (below) of wheat genotypes GURI 6 UNAND and IS-Jarissa in response to various level of gamma ray irradiation
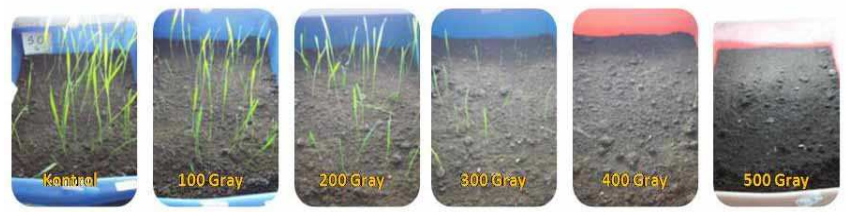

Fig. 4. Wheat young plants at 3 WAP (Week After Planting) in response to various level of gamma ray irradiation ( 0 Gray; $0,1 \mathrm{kGy} ; 0,2 \mathrm{kGy} ; 0,3 \mathrm{kGy}$; $0,4 \mathrm{kGy}$, and $0,50 \mathrm{kGy})$

\section{CONCLUSIONS}

Data of this research concluded that the higher the dose of gamma ray irradiation the lower the growth rate of the wheat tested. The effective doses of gamma radiation were 0.2 and $0.3 \mathrm{kGy}$. No wheat grown observed from the treatment groups of $0.5 \mathrm{kGy}$ gamma radiation and higher.

\section{ACKNOWLEDGMENT}

The research reported here was financially funded by the Directorate of Research and Community Services of Higher Education (DP2MDIKTI) through the University Competitive Research Scheme (Penelitian Unggulan Perguruan Tinggi). We would like to express our gratitude for the opportunity given to conduct the research. All other parties for any kind of assistances are very much appreciated.

\section{REFERENCES}

[1] Wahida. 2011. Academic Discussion Forum (ADF): "Nilai ekonomi produksi gandum di Indonesia." PPIA University of Adelaide, 24 Mei 2011, The University of Adelaide - North Tce campus, Board Room, School of Agriculture, Food and Wine, The University of Adelaide

[2] Badan Pusat Statistik (BPS) 2015. www.bps.go.id. [diakses tanggal 11 April 2015].

[3] Suliansyah, I., M. Kasim, I. Chaniago, dan Reflinaldon. 2011. Uji Adaptasi Tanaman Gandum (Triticum aestivum L.) Di Sumatera Barat Program Studi Agroekoteknologi. Fakultas Pertanian Universitas Andalas, Padang. Suliansyah, I., M. Kasim, I. Chaniago, dan Reflinaldon. 2011. Uji Adaptasi Tanaman Gandum (Triticum aestivum L.) Di Sumatera Barat Program Studi Agroekoteknologi. Fakultas Pertanian Universitas Andalas, Padang.

[4] Suliansyah, I, Winarto, I. Chaniago, Reflinaldon, L. Hakim, C. Herison, Trikoesoemaningtyas, D. Murdono, Damanhuri, dan M. Azrai. 2012. Kajian Potensi Produksi Gandum di Indonesia Dalam Rangka Pengembangan Gandum Nasional dan Pembentukan Kampung Industri Berbasis Gandum. Laporan Akhir Tahun I Program Penelitian Unggulan Strategis Nasional, Bidang Kajian Unggulan Ketahanan Pangan. Fakultas Pertanian Universitas Andalas, Padang.

[5] Suliansyah, I, Winarto, I. Chaniago, Reflinaldon, L. Hakim, C. Herison, Trikoesoemaningtyas, D. Murdono, Damanhuri, dan M. Azrai.. 2013. Kajian Potensi Produksi Gandum di Indonesia Dalam Rangka Pengembangan Gandum Nasional dan Pembentukan Kampung Industri Berbasis Gandum. Laporan Akhir Tahun II Program Penelitian Unggulan Strategis Nasional, Bidang Kajian Unggulan Ketahanan Pangan. Fakultas Pertanian Universitas Andalas, Padang

[6] Suliansyah, I, Winarto, I. Chaniago, Reflinaldon, L. Hakim, C. Herison, Trikoesoemaningtyas, D. Murdono, Damanhuri, dan M. Azrai.. 2014. Kajian Potensi Produksi Gandum di Indonesia Dalam Rangka Pengembangan Gandum Nasional dan Pembentukan Kampung Industri Berbasis Gandum. Laporan Akhir Tahun III Program Penelitian Unggulan Strategis Nasional, Bidang Kajian Unggulan Ketahanan Pangan. Fakultas Pertanian Universitas Andalas, Padang.

[7] Allard, R.W. 1992. Pemuliaan Tanaman. Terjemahan Manna. Rineka Cipta. Jakarta. 336 hal

[8] Poehlman. J. M. and D. A. Sleper. 1995. Breeding Field Crop. Lowa State University. Press Ames. Iowa.

[9] Djojosoebagio, S. 1988. Dasar-dasar Radioisotop dan Radiasi dalam Biologi. PAU-IPB. Bogor.

[10] Ismachin, M. 1988. Pemuliaan Tanaman dengan Mutasi Buatan. Pusat Aplikasi Isotop dan Radiasi BATAN. Jakarta. Tidak Dipublikasikan.

[11] Mugiono, I. Dwimahyani, dan Haryanto. 2006. Pemanfaatan Teknik Nuklir pada Tanaman Padi. Pusat Aplikasi Teknologi Isotop dan Radiasi. Badan Tenaga Nuklir Nasional.

[12] Ahloowalia, B.S. and M. Maluszynski, 2001. Induced mutations - A new paradigm in plant breeding. Euphytica 118:167-173.

[13] van Harten, A.M. 1998. Mutation Breeding: Theory and Practical Appliation. Cambridge University Press. Cambridge.

[14] Mak, C., A. A. Mohamed, K. W. Liew and Y. W. Ho. 1996. Double tray technique for the screening of fusarium wilt resistance in banana nursery plants. Malaysian J. of Sci.

[15] Ishak. 2000. Improvement of banana quality trought induced mutation. Paper Presented on Seminar of Methodology for Plant Mutation Breeding: Screening for Quality. Jakarta.

[16] Zarmiyeni, Kasli, M. Kasim, I. Suliansyah, N. Nasir, dan Ishak. 2009. Induksi Resistensi Pisang Barangan Terhadap Penyakit Layu Fusarium (Fusarium oxysporum f. sp. cubense) Melalui Mutagenesis In Vitro. Disertasi. Tidak Dipublikasikan. Program Pascasarjana, Universitas Andalas, Padang.

[17] Suliansyah, I., E. Swasti, A.A. Syarif, dan H. Alfi. 2010. Perakitan Kultivar Padi Lokal Sumatera Barat Berumur Genjah (105-124 HSS) dan Berdaya Hasil Tinggi ( $\geq 8$ Ton/Ha) Melalui Pemuliaan Mutasi Untuk Mendukung Keberhasilan IP Padi 400. Laporan KKP3T, Lembaga Penelitian Universitas Andalas Bekerjasama dengan Badan Penelitian dan Pengembangan Pertanian. Padang. 